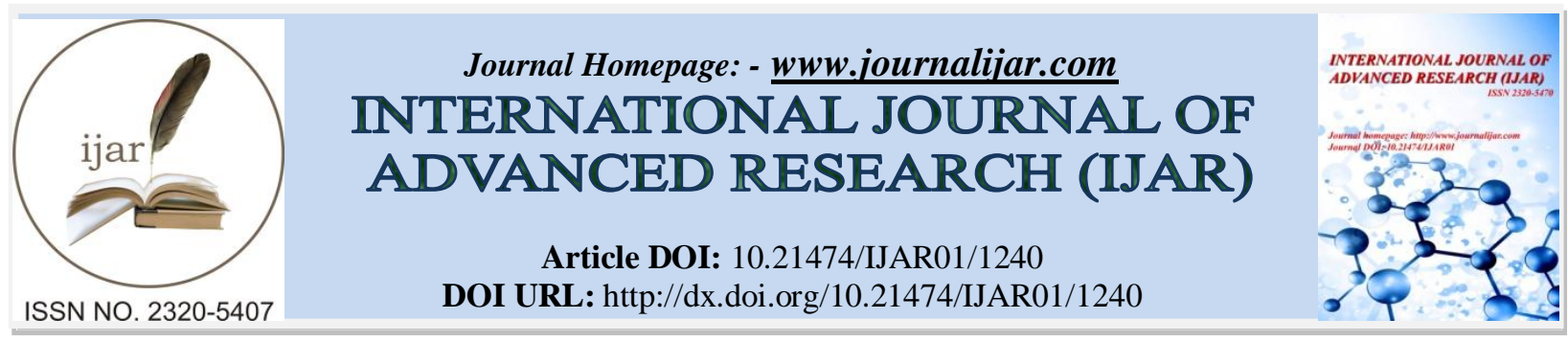

RESEARCH ARTICLE

\title{
SOCIAL IMPLICATIONS OF CLIMATE CHANGE.
}

Ufuk GULTEKIN $^{1}$, Dilek BOSTAN BUDAK ${ }^{1}$ and Zeynep ZAIMOGLU ${ }^{2}$.

1. University of Cukurova, Agricultural Economics Department, Adana, Turkey.

2. University of Cukurova, Environmental Engineering Department, Adana, Turkey.

\section{Manuscript Info}

Manuscript History

Received: 19 June 2016

Final Accepted: 22 July 2016

Published: August 2016

Key words:-

Climate, migration, drought.

\begin{abstract}
Climate has been changing and not all effects of global climate change should be seen as unfavorable. Although most of the likely future effects consist of elements that are hazardous to human life and environment. Increasing frequency of extreme weather events and sea level rise, as well as changes in temperature and rainfall will bring about social problems like migration, water shortages, low crop productivity and health issues. Today, more than 1 billion people are struggling with hunger and poverty; similarly 1.5 billion people are struggling with diseases related to overeating. This study was composed as a result of a collection of works, with the aim of revealing the social effects of climate change.
\end{abstract}

Copy Right, IJAR, 2016,. All rights reserved.

\section{Introduction:-}

Latest climatic data reveal a $0.4{ }^{\circ} \mathrm{C}$ to $0.8{ }^{\circ} \mathrm{C}$ increase in average global temperature, since mid-19th century. Higher latitudes manifested greater tendencies of warming, especially for the last 10 years. During the last century, ocean temperatures increased, consequently glaciers melted, and as a result, due to increased seawater volume, sea levels have risen by 10 to $20 \mathrm{~cm}$. Despite the growing oceanic, climatic and atmospheric knowledge scientists are not convinced that the increase in global temperature average causes drought, floods and hurricanes. On the other hand, nobody knows the direct consequences of not enforcing preventive technologies and laws concerning the accumulation of greenhouse gases in the atmosphere. Moreover, there is not enough information on the economic costs of such an enforcement. (CBO, 2003; Erkan, et al., 2007.)

IPCC's 2002 synthesis report states that the causes of these extreme weather events are related to climate. For example, El Nino hurricanes of 1997 and 1998 are causes of great number of deaths, environmental and infrastructural damages. Changeable and unusual weather events are a main topic of research. Floods and drought proliferating in last couple of years cause great economic burdens, and disturb economic and social systems. For example, inflation-adjusted costs of global disasters caused by unexpected weather events have increased three times more and number of events has increased 13 to 72 between 1950s and 1990s. Weather events that cannot be described as catastrophic, likewise, cost more. The number of weather related disasters is three times higher than non-weather related disasters. Causes of this trend of past 50 years are, both, socio-economical (population increase, improved prosperity, urbanization of delicate regions), and related to regional climates (alterations of rainfall, and floods) (IPCC, 2001a). 
Scientific data related to climate change, and especially, global warming are stronger, compared to the ones in the past. Researches related to predicting global warming estimate a 0.3 to $1.3{ }^{\circ} \mathrm{C}$ increase in global temperatures for the next 30 years. Another related research estimates global warming, between years 1990 and 2100 , to be $2.4^{\circ} \mathrm{C}$. According to this study the increase in global temperatures, with $95 \%$ probability, will be between $1{ }^{\circ} \mathrm{C}$ and $4.9^{\circ} \mathrm{C}$ (CBO, 2003; Erkan, et al., 2007).

Global climate change scenarios have been developed by some other scientists (Darwin et al., 1995). Goddard Institute fo Space Studies, Geophysical Fluid Dynamics Laboratory, The United Kingdom Meteorological Office and Oregon State University scientists, using their projection results and studies, have estimated that global warming will be between $2.8{ }^{\circ} \mathrm{C}$ and $5.2^{\circ} \mathrm{C}$, while changes in rainfall will be between $\% 7.8$ and $15.0 \%$ (IPPCC, 2001a; Erkan et al., 2007).

Climate change will have an impact on agriculture. Although scientists have not reached a consensus regarding the effects of climate change on agriculture, some subjects are agreed upon. According to IPCC estimates, tropical and subtropical regions have the greatest risk of floods and low crop productivity.

\section{Accordingly, in some areas:-}

- Long term competitive and efficient farming will be at risk.

- Rural population will, increasingly, be anxious.

- Environmental consequences of agriculture, regarding soil and water resources, will become frequent and contentious problems.

In the following years changes in climate are expected. But what will occur is not precisely certain. Most important issue is whether these changes will be permanent or intermittent.

Process of climate change is lengthy. Decisions made during the following, or the next, decade will have consequences in the following century, or even, later. Thus, technological advancements and the aim and efficiency of their use will be the determining factors of this issue (IPCC, 2001b; Erkan et al., 2007).

It is quite natural for climate change to manifest itself differently in various regions. For example, a $2{ }^{\circ} \mathrm{C}$ increase in temperatures near continental climate and a same amount of increase in subtropical climate will have different consequences. Recently, scientists from various disciplines conduct researches in various parts of the world regarding all-around effects of climate change. There is an urgent need for inter-disciplinary researches and studies, in different parts of the globe, on climatic events, with the aim of finding their impacts on agriculture, social processes and corporate structures and revenues. This study was composed as a result of a collection of works, with the aim of revealing the social effects of climate change.

\section{Social Implications of Global Climate Change:-}

Not all effects of global climate change should be seen as unfavorable. Although most of the likely future effects consist of elements that are hazardous to human life or environment, it is plausible to point out advantageous societies or countries. As a result of climate change in areas (northern latitudes) formerly inconvenient for agriculture or unfavorable for habitation, due to rough weather conditions, improvements in both living conditions and agriculture are some of the expected favorable results of climate change. But the primary concerns of climate change studies and action plans are negative effects, rather than positive, due to the impact on, both, global habitats, and densely populated areas.

It seems inevitable for climate change to be seriously negative for people in the future, as it has been in the past. Incresing frequency of extreme weather events and sea level rise, as well as changes in temperature and rainfall will bring about social problems like migrations, water shortages, lowered crop productivity and health issues. In the face of the fact that climate change will increase the risk of disasters like hurricanes, drought and floods, the question of how people and societies will be affected is interesting. 
According to IPCC 2014 Climate Change Report, expected future effects of climate change, with at least 95\% probability, are (www.yesilist.com, 2014):

- The risk of deaths, injuries and damages to human environments in small island states, other small islands and coastal areas due to the rise of sea levels, floods and hurricanes,

- Due to sudden flooding, the risk of damages to settlements and of disease among urban populations in some continental areas,

- Systemic risks concerning health and emergency aid services, due to infrastructural damages caused by extreme weather events,

- Risk of deaths and diseases for more fragile individuals of urban populations (elderly, sufferers of respiratory diseases, etc.) and outdoor personnel, in both rural and urban areas, during heat waves,

- In accordance with the changes in rainfall, floods, drought and increase in temperatures, risk of annihilation of food supply systems and weakened food safety, especially for the poor,

- Due to insufficient access to drinking and irrigation water and decline of agricultural production, risk of lessened subsistence of farmers and villagers, especially in semiarid regions,

- Risk for marine and coastal ecosystems, and the biological diversity they provide to become extinct, especially in tropical and Arctic regions,

- Risk of both inland and marine ecosystems, and the diversity and ecosystem services people benefit in these areas, to become depleted.

Determination of these and other similar risks, and actions that aim to relieve and adapt to these risks are important. Studies that focus on determining the possible effects of climate change within 30,50 and 100 years are being conducted, and courses of action aiming to prevent or control these effects are planned according to the findings of these studies.

\section{Climate Change, Foods and Food Safety:-}

According to the predictions of Agriculture and Food Organization (FAO), in the year 2050 world population will be 9.1 billion. It is emphasized that, in order for the growing population to be nourished, until 2050 food production must be doubled, while using natural resources sustainably. Again according to FAO data, in order to meet future demands, by 2050, wheat production have to be increased by 1 billion tons per year, while meat production should increase by 200 million tons, reaching 463 million tons (Mimar ve Mühendis Dergisi, 2014).

As a result of the negative impact on food prices, and also rural sustenance and working conditions, most predictions point out climate change's threat to the food production. This situation can cause the amount of people living under hunger threshold, now $10 \%$, to double, becoming $\% 20$, by the year 2050 . Because of insufficient resources, low income rate and level of technological advancement developing countries will be the least adaptive to the alterations. Africa, Southeast Asia and a section of Central America will be the most affected regions by climate change, due to the amount of developing and under developed countries populating these areas. In countries where most of the workforce, income and nourishment of the population is dependent on local farming, sustenance of millions of people and food safety will be at risk (Mimar ve Mühendis Dergisi, 2014).

According to the research made, in mid-high latitudes, where temperature increase is between $1{ }^{\circ} \mathrm{C}$ and $3{ }^{\circ} \mathrm{C}$, depending on the crop, product efficiency can be improved, if only slightly, conversely it will be impaired in some regions. It is predicted that in lower latitudes, especially places experiencing seasonal droughts and tropical regions, crop productivity will be impaired, even if the warming happens to be $1^{\circ} \mathrm{C}$ to $2^{\circ} \mathrm{C}$, and this in turn will increase the risk of hunger (Kılıç, 2009).

Some of the important applications aiming at alleviating the effects of climate change over food safety are directed to increase local food production and consumption. Preventive measures ensuring the existence of small and median agricultural businesses are highly important. Another important topic is to support and prioritize the strategies and efforts (use of local and adaptive seeds) of adapting to climate change. Political precautions will enable us to minimize potential short term implications.

If preventive measures are neglected, as a result of climate change in products like rice, corn, soy, peas and millet the amount of zinc and iron will be lessened by the year 2050. Considering that populations of under developed and developing countries, which amount to 3 billion, get $70 \%$ of their essential nourishments through wheat, rice and 
pulses, it is obvious that the risks posed by climate change are not limited to food scarcity and availability, they also include risks regarding nutritional values of agricultural products.

\section{Climate Change and Climate Migration:-}

Migratory delocalization of people as a result of natural disasters and environmental problems, such as desertification, floods, drought or tsunamis, is called climate migration (Ziya, 2012). The presumption that, due to climate change, millions of people will have to leave their place of dwelling, in order to settle in a safer area, is placed in the elaborated scenarios.

According to predictions, around mid-century 200 million people will migrate as a consequence of climate change. According to scientists, migration is one of the ways for people to adapt to climate change. According to the researches conducted, as a result of climate change water resources will be depleted, crop productivity will be reduced, extreme weather events will be frequent and bio-diversity around the globe will be lessened, and consequentially people will want to leave the areas where it's hard to live due to increased human fragility. Main causes of migration will be (Çeber, 2013):

- The expected sea level rise that will occur with the melting of glaciers: according to the studies $10 \%$ of world population reside within 10 meters distance from sea level. The sea level rise can have negative consequences for these habitats.

- The possible decline of agricultural production and efficiency: while people will struggle with hunger, migrations caused by famine will be compulsory. Famine will cause deaths and disease.

- Increased malnutrition and heat will be a threat to human health. Due to heat and lack of nutrition an increase in epidemics will be seen.

- As a result of melting of glaciers in high latitudes clean water resources will lessened.

- Increase in rainfall intensity will cause extreme weather events like hurricanes, storms and floods.

In addition to the above stated causes, pollution of air, water and soil resources will trigger migrations to places that are more habitable. Of course occurrence of these migrations will bring about complications. It is expected that, especially, as a consequence of migrations unemployment, poverty and crime rates will soar. It is predicted that one of the main disagreements in international politics will be global migrations.

\section{Climate Change and Poverty:-}

In order to provide nourishment for the world population, which will reach 9 billion during 2050s, production will have to increase accordingly. Today, more than 1 billion people are struggling with hunger and poverty, similarly 1,5 billion people are struggling with diseases related to overeating.

One of the most important consequences of climate change will be related to production, alongside famine and hunger. It is certain that agriculture will be affected differently in many countries. Research conducted point out that in the production areas crop productivity, sown land and efficiency can be decreased dramatically. It is expected that, in northern countries there will be increased efficiency, whereas in the south efficiency will be decreased. Moreover, international agreements related to the limiting of $\mathrm{CO}_{2}$ emissions are important factors that directly upset developed countries' industrial activity, and consequentially, income per capita.

It is possible to classify countries, according to the climate change's impact: countries that suffer the most damage, countries that suffer less damage and countries that profit. Of course, due to the unequal distribution of effects, regarding countries, on a global scale, imbalances regarding income distribution will emerge, or the ongoing imbalances will become severe.

The income difference between under developed or developing countries, as well as regions and countries which will suffer the most due to climate change, and developed countries and countries that will benefit from climate change, will be greater, and in some countries poverty rate will be highest. This situation will bring about many social problems.

\section{Climate Change and Health:-}

Due to increased number of epidemics, heat waves, instability of weather conditions and reduced quality of air, caused by climate change, serious health problems will be experienced. 
Causes of epidemics, caused by climate change, as vectorials of disease; temperature, vector metabolic rate, spawn production, increase of blood use; rainfall, abundant breeding grounds; humidity; indirectly, suitable conditions for vector placement, and increase of areas providing these conditions, will accordingly cause epidemic areas to increase. Climate is the most important factor of malaria propagation. High temperatures and rain play a catalytic role in the increase of malaria patients. Studies have determined a correlation between high temperatures and malaria (TGNA, 2008).

Additionally, while climate change poses threats to health, it, also, will present some new opportunities. Some new health issues will be developments like high mortality rates during summer months, increased risk of skin cancer, food poisoning, malaria, spreading of diseases as a result of migrations. Developments like low disease and mortality rates during winter, increased duration of summer will have results like availability of a variety of foods, and a more active life, during winter, will present new opportunities for health related activity. Nevertheless, on a larger scale, it is expected that rising temperatures will have greater negative consequences regarding health, in developing countries, than its benefits (Kılıç, 2009).

\section{Climate Change, War and Security:-}

The sea level rise, water shortages and drought, caused by climate change, will result in continental migrations and resource related wars (water wars), as some regions become uninhabitable.

Pressures and setbacks, caused by global climate change's physical effects (drought, floods, heat waves, wildfires, powerful storms, epidemics and sea level rise), related to water, agriculture, health, energy and environment are forcing countries to revise their approach to the subject of security. Thus, as the correlation between recent unfavorable physical events and climate change is proved by scientific evidence, countries have included national security and climate change to their prioritized activity (Kibaroğlu, 2015).

\section{Climate Change and Unemployment:-}

Another important possible consequence of climate change is the issue of unemployment. Especially the reductions in agricultural population and production can bring about an issue of personnel deficiency in agricultural activity and agricultural industry. Possible migrations on a global scale caused by above mentioned factors will escalate the problem of unemployment.

\section{References:-}

1. CBO. (2003): "The Economics of Climate Change: A Primer", The Congress of the United States, Congressional Budget Office Publications (www.cbo.gov), USA.

2. IPCC. (2001a): "Climate Change 2001: Synthesis Report. A Contribution of Working Groups I, II, and III to the Third Assessment Report of the Integovernmental Panel on Climate Change [Watson, R.T. and the Core Writing Team (eds.)]." Cambridge University Press, Cambridge, United Kingdom, and New York, NY, USA, 398 pp.

3. IPCC. (2001b): "Climate Change 2001: The Scientific Basis. Contribution of Working Group I to the Third Assessment Report of the Intergovernmental Panel on Climate Change. [Houghton, J.T.,Y. Ding, D.J. Griggs, M. Noguer, P.J. van der Linden, X. Dai, K. Maskell, and C.A. Johnson (eds.)].” Cambridge University Press, Cambridge, United Kingdom and New York, NY, USA, 881pp.

4. Erkan, O., U. Gültekin, C. Oğuz. (2007): "Economic Analysis of Climate Changes on Agricultural Production Systems and Identification of Policy and Institutional Measures in Cukurova and Central Anatolia Regions", ICCAP Project Turkish and Japanese Groups Final Reports. The Research Project on the Impact of Climate Change on Agricultural Production System in Arid Areas. Publication Number 11-13, March 2007, Kyoto, Japan.

5. Verner, D.(2010): "Reducing Poverty, Protecting Livelihoods, and Building Assets in a Changing Climate." Washington, DC: World Bank. http://elibrary.worldbank.org/content/book/9780821382387;jsessionid=52r6hrhl1dim7.z-wb-live.

6. Mimar ve Mühendis Dergisi. (2014): “Mimar ve Mühendisler Grubu Dergisi”, Say1: 77, İstanbul.

7. http://www.yesilist.com/cms.php?id=1416 (erişim tarihi: 22 Mart 2015).

8. Ziya, O. (2012): "Mülteci-Göçmen Belirsizliğinde İklim Mültecileri", Türkiye Barolar Birliği Dergisi, http://tbbdergisi.barobirlik.org.tr/m2012-99-1156.

9. Kılıç, C. (2009): "Küresel İklim Değişikliği Çerçevesinde Sürdürülebilir Kalkınma Çabaları ve Türkiye”. C.Ü. İktisadi ve İdari Bilimler Dergisi, Cilt 10, Sayı 2. 
10. Çeber, Z.P. (2013): “İklim Değişikliği ve Göç” (http://yesilgazete.org/blog/2013/02/23/iklim-degisikligi-vegoc-zeynep-pelin-ceber/).

11. TBMM. (2008): "Türkiye Büyük Millet Meclisi Küresel Isınmanın Etkileri ve Su Kaynaklarının Sürdürülebilir Yönetimi Konusunda Kurulan $(10 / 1,4,5,7,9,10,11,13,14,15,16,17)$ Esas Numaralı Meclis Araştırması Komisyonu Raporu", Ankara.

12. Kibaroğlu, A. (2015): "Küresel İklim Değişikliklerinin Uluslararası Güvenliğe Etkileri” (http://vizyon21yy.com/documan/genel_konular/Milli\%20Guvenlik/Strateji/Kuresel_Iklim_Degisikliklerinin_U luslarasi_Guvenlige_Etkileri.pdf.), (erişim tarihi: 22 Mart 2015). 